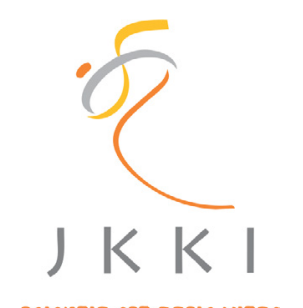

Jurnal Kedokteran dan Kesehatan Indonesia

Indonesian Journal of Medicine and Health

Journal homepage : www.journal.uii.ac.id/index.php/JKKI

\title{
In vitro anti-inflammatory activities of ethanolic extract Elephantopus scaber leaves
}

\author{
Tomy Nurtamin*1, I Putu Sudayasa ${ }^{1}$, Tien $^{1}$ \\ ${ }^{1}$ Faculty of Medicine, Universitas Haluoleo, Kendari, Indonesia
}

Original Article

\begin{tabular}{l}
\hline \\
\hline ART ICLE IN F O \\
\hline Keywords: \\
Anti-inflammatory activities, \\
ethanolic extract of Elephan- \\
tophus scaber, \\
human red blood cell (HRBC) \\
membrane stabilization, \\
heat-induced hemolysis, \\
membrane stabilization \\
*Corresponding author: \\
tomymedica@gmail.com \\
\hline D0I : 10.20885/JKKI.Vol9.Iss1.art9 \\
History: \\
Received: June 14, 2017 \\
Accepted: April 24, 2018 \\
Online: April 30, 2018 \\
\hline
\end{tabular}

Copyright @2018 Authors. This is an open access article distributed under the terms of the Creative Commons Attribution-NonCommercial $\quad 4.0$ International Licence (http:// creativecommons.org/licences/ by-nc/4.0/).

\section{ABSTRACT}

Background: Inflammation is a protective physiological response to tissue injury that can be caused by harmful stimuli. If the inflammatory process is prolonged and cannot restore to homeostatic conditions, this may lead to pathological effects that can damage cells and cause various diseases. Elephantopus scaber is a plant that can easily be found in Indonesia. Elephantopus scaber is a type of plant that is often used as a traditional medicines. Several studies have shown that the compound bioactive content contained in plants has enormous potential as alternative medicine.

Objective: This present study was to investigate the anti-inflammatory activity of ethanolic extract of Elephantopus scabe leaves.

Methods: The Elephantopus scaber leaves were extracted using ethanol solvent into different concentration $(50 \mathrm{mg} / \mathrm{mL}, 100 \mathrm{mg} / \mathrm{mL}$ and $120 \mathrm{mg}$ / $\mathrm{mL}$ ). Diclofenac sodium was used as the standard. Anti-inflammatory assays were performed by the human red blood cell (HRBC) membrane stabilization method and heat-induced hemolysis method. Phytochemical screening that used in the present study was a conventional method.

Results: Phytochemical screening showed the presence of flavonoids, tannins and saponins. In the present study, ethanolic extract of Elephantopus scaber leaves has anti inflammatory activity by protecting the stability of red blood cell membrane. The highest protection capability possessed by the ethanolic extract of Elephantopus scaber leaves in both human red blood cell (HRBC) membrane stabilization method and heatinduced hemolysis method was at a concentration of $100 \mathrm{mg} / \mathrm{mL}$.

Conclusion: The ethanolic extract of Elephantophus scaber has antiinflammatory activities by in vitro assays.

Latar Belakang: Inflamasi merupakan respon protektif fisiologi terhadap cedera pada jaringan yang dapat disebabkan oleh stimulus berbahaya. Jika proses inflamasi berlangsung lama dan tidak dapat mengembalikan ke kondisi homeostasis, dapat menyebabkan efek patologis yang dapat menyebabkan kerusakan sel dan menimbulkan berbagai penyakit. Elephantopus scaber merupakan tumbuhan yang dapat dengan mudah dijumpai di Indonesia. Elephantopus scaber merupakan tumbuhan yang sering digunakan sebagai obat-obat tradisional. Berbagai penelitian menunjukkan bahwa senyawa bioaktifyang terkandung dalam tumbuh-tumbuhan memiliki potensi yang besar untuk dijadikan sebagai alternatif obat-obatan.

Tujuan Penelitian: Penelitian ini bertujuan untuk mencari aktifitas anti-inflamasi ekstrak etanol daun Elephantopus scaber.

Metode: Daun Elephantopus scaber diekstraksi dengan menggunakan etanol dan dibuat menjadi 
konsentrasi yang berbeda-beda (50 mg/mL, 100 $\mathrm{mg} / \mathrm{mL}$, and $120 \mathrm{mg} / \mathrm{mL}$ ). Natrium diklofenak merupakan obat standar. Anti-inflamasi di ukur dengan menggunakan metode stabilisasi membran sel darah merah dan metode hemolisis yang diinduksi panas. Skrining fitokimia yang digunakan dalam penelitian ini adalah metode konvensional.

Hasil: Skrining fitokimia menunjukkan adanya flavonoid, tanin, dan saponin yang terkandung dalam ekstrak. Pada penelitian ini, ekstrak etanol daun Elephantopus scaber memiliki aktifitas anti -inflamasi dengan melindungi stabilitas membran sel darah merah. Kemampuan proteksi yang paling tinggi yang dimiliki oleh ekstrak etanol daun Elephantopus scaber baik metode stabilisasi membran sel darah merah maupun hemolisis yang diinduksi panas adalah pada konsentrasi $100 \mathrm{mg} /$ $m L$.

Kesimpulan: Ekstrak etanol daun Elephantopus scaber memiliki aktifitas anti-inflamasi dengan pengujian in-vitro.

\section{INTRODUCTION}

Inflammation is a protective physiological response to tissue injury that can be caused by a physical trauma, destructive chemicals agent and microbiological agent infections. The healing processes in inflammation can occur with neutralizing harmful stimuli, repairing damaged tissue and fighting the microbial infection process by activating the immune response..$^{1-3}$ In inflammation, there is a release of vasoactive, chemoattractant and proliferative substances that cause transfer of plasma fluid and mobilization of phagocytic cells to the site of inflammation. Inflammation is characterized by symptoms such as redness, heat, pain, swelling, and loss of function. Although inflammation plays an important role in physiological processes, if the inflammatory process is prolonged and cannot restore to homeostatic conditions, this may lead to pathological effects that can damage cells and cause various diseases. ${ }^{1,3,4}$

Non-steroidal anti-inflammatory drugs (NSAIDs) are often used to treat pain. NSAIDs act by inhibiting cyclooxygenase (COX) enzymes or protecting the lysosome membranes from breakdowns. COX is an enzyme that is responsible for the formation of prostaglandin. COX consists of COX-1 and COX-2 isoforms that have different roles. COX-1 is constitutively expressed in almost all tissues such as bloodvessels, kidneys and stomach. It is expressed in a physiological state to maintain the functioning of tissue homeostasis. In the other hand, COX-2 is expressed in a pathological condition. COX-2 is induced by proinflammatory agents, hormones, and growth factors. Most of NSAIDs act by inhibiting COX-1 and COX-2, therefore, this mechanism often cause adverse effects on cardiovascular, kidney, and gastrointestinal tracts. ${ }^{2,5-7}$

Since ancient times, the knowledge and utilization of traditional medicinal plants have long been done. This often becomes the basis for the development and discovery of new alternative medicine. Elephantopus scaber is a plant that can easily be found in Indonesia including in the Southeast Celebes. ${ }^{8}$ Elephantopus scaber is a type of plant that is often used as a traditional medicine to treat headaches, fever, diarrhea, and hepatitis. ${ }^{9-11}$ Several studies have shown that the compound bioactive content contained in plants has enormous potential as antioxidants, antiinflammatory and anti-cancer. ${ }^{12-14}$ The present study aimed to investigate the anti-inflammatory activity of ethanolic extract of Elephantopus scaber.

\section{METHOD \\ Drugs and chemicals}

The diclofenac sodium salt was obtained from Tocris Biosciences, McKinley Place NE, Minneapolis, USA. Alsever's solution was obtained from Sigma Aldrich, Saint Louis, Missouri, USA. Sodium hydroxide, chloroform, sulfuric acid, acetic anhydride and other agents were obtained from the local supplier.

\section{Preparation of extract}

The leaves material Elephantopus scaber, was collected from South Konawe, Southeast Celebes, Indonesia. The extraction was performed using standard procedures.The plant leaves were thoroughly washed with tap water. Then the leaves were dried and made into the powder. Dry powder material was extracted by maceration 
method using ethanol $70 \%$ solvent and then was evaporated by vacuum rotary evaporator.

\section{Preliminary phytochemicals screening}

Preliminary phytochemical screening was perfomed using conventional method. ${ }^{15}$

\section{Alkaloids test}

The powder samples of Elephantopus scaber ( $1 \mathrm{~g})$ were taken in a conical flask and added ammonia solution ( $3 \mathrm{~mL}$ ). It was allowed to stand for few minutes to evaluated free alkaloids. Chloroform $(10 \mathrm{~mL})$ was added to the conical flask shaken by hand gently and then filtered. The chloroform was evaporated from the crude extract by water bath and added Mayer's reagent $(3 \mathrm{~mL})$. The presence of alkaloid was characterized by the formation of a cream color precipitation.

\section{Flavonoids test}

The ethanolic extract of Elephantopus scaber $(1 \mathrm{~mL})$ was taken in a test tube and added fewdrops of dilute $\mathrm{NaOH}$ solution. The presence of flavonoids was characterized by a change of color from intense yellow to colorless when added a few drops of dilute acid.

\section{Tannins test}

The ethanolic extract of Elephantopus scaber ( $3 \mathrm{~mL}$ ) was taken in the test tube and diluted with chloroform and an acetic anhydride (1 $\mathrm{mL}$ ) was added. The presence of tannins was characterized by a green color that is formed when there is a sulfate $(1 \mathrm{ml})$ addition that is carefully on the side of the test tube to the solution.

\section{Steroids test}

The crude plant extract Elephantopus scaber (1 $\mathrm{mg}$ ) was taken in a test tube and dissolved with chloroform $(10 \mathrm{~mL})$, then added the same volume of concentrated sulfuric acid to the test tube by sides. The presence of steroids was characterized by a change in color to the red and the sulfuric acid layer appears yellow with green fluorescence.

\section{Triterpenoids test}

The dry crude plant extract Elephantopus scaber $(5 \mathrm{mg})$ was dissolved in chloroform $(2 \mathrm{~mL})$ and then acetic anhydride $(1 \mathrm{~mL})$ was added to it. Concentrated sulphuric acid (1 $\mathrm{mL})$ was added to the solution. The presence of triterpenoids was characterized by the formation of reddish violet color.

\section{Saponins test}

The ethanolic extract of Elephantopus scaber $(1 \mathrm{~mL})$ was taken in a test tube and diluted with $20 \mathrm{~mL}$ of distilled water. It was shaken by hand for 15 minutes. The presence of saponins was characterized by a layer of the foam obtained at the top of the test tube.

\section{Anti Inflammatory Assays \\ The human red blood cell (HRBC)} membrane stabilization method

The method was used for the present study following the methodology of Gupta et al. (2013) with some modification. ${ }^{16}$ The blood was collected from a healthy human volunteer who had not taken any NSAIDs for 2 weeks prior to the experiment and mixed with equal volume of Alsever solution ( $2 \%$ dextrose, $0.8 \%$ sodium citrate, $0.5 \%$ citric acid and $0.42 \% \mathrm{NaCl}$ ) and centrifuged at $3.000 \mathrm{rpm}$. The packed cells were washed with isosaline and $10 \%$ suspension was made. Different concentration of extracts was prepared (50,100 and $120 \mathrm{mg} / \mathrm{ml}$ ) using DMSO and to each concentration, $1 \mathrm{ml}$ of phosphate buffer, $2 \mathrm{ml}$ hypo saline and $0.5 \mathrm{ml}$ of HRBC suspension were added. It was incubated at $37^{\circ} \mathrm{C}$ for 30 minutes and centrifuged at 3.000 rpm for 20 minutes and the hemoglobin content of the supernatant solution was estimated by spectrophotometric at $560 \mathrm{~nm}$. Diclofenac sodium $(100 \mathrm{mg} / \mathrm{ml})$ was used as a standard drug and a control was prepared by omitting the extracts. The procedures were performed in duplo. Mean values of the duplo were considered.

Percentage Protection (\%) = 100 - [(optical density (OD) of sample/OD of control) X 100] 


\section{Heat-induced hemolysis method}

The reaction mixture $(2 \mathrm{ml})$ consisted of $1 \mathrm{ml}$ of test sample solution and $1 \mathrm{ml}$ of $10 \%$ RBCs suspension, instead of test sample the only saline was added to the control test tube. Diclofenac sodium $(100 \mathrm{mg} / \mathrm{ml})$ was used as standard drug. All the centrifuge tubes containing reaction mixture were incubated in water bath at $56^{\circ} \mathrm{C}$ for 30 minutes. At the end of the incubation, the tubes were cooled under running tap water. The reaction mixture was centrifuged at $2500 \mathrm{rpm}$ for 5 minutes and the absorbance of the supernatants was taken at $560 \mathrm{~nm}$. The experiment was performed in duplo for all the test samples. Mean values of the duplo were considered.

Percentage of Protection (\%) = $100-[$ (OD of sample $/$ OD of control) X 100]

\section{RESULTS \\ Phytochemical Screening}

The phytochemicals screening of Elephantophus scaber showed the presence of phytochemical various constituents (Table 1 ).

Table 1. Phytochemical screening of Elephantophus scaber

\begin{tabular}{lc}
\hline Phytochemical Test & Result \\
\hline Alkaloids & - \\
Flavonoids & + \\
Tannins & + \\
Steroids & - \\
Triterpenoids & - \\
Saponins & + \\
\hline
\end{tabular}

The human red blood cell (HRBC) membrane stabilization method

In the present study, it can be seen that each concentration of ethanol extract could provide protection against stabilization of human red blood cell membrane (Table 2). Based on the present study, ethanolic extract of Elephantopus scaber leaves has the potential as the antiinflammatory. In the present study, we found that the highest protection capability possessed by ethanol extract Elephantopus scaber was at concentration $100 \mathrm{mg} / \mathrm{mL}$.

Table 2. Effect of ethanolic extract of Elephantopus scaber on HRBC membrane stabilization method

\begin{tabular}{cc}
\hline Concentration & \% Protection \\
\hline $50 \mathrm{mg} / \mathrm{mL}$ & 98.40 \\
$100 \mathrm{mg} / \mathrm{mL}$ & 99.04 \\
$120 \mathrm{mg} / \mathrm{mL}$ & 98.28 \\
Standard & 98.58 \\
\hline
\end{tabular}

\section{Heat-induced hemolysis method}

In the present study, it can be seen that each concentration of ethanol extract also could provide protection against heat-induced hemolysis (Table 3). In the present study, we also found that the highest protection capability possessed by ethanolic extract of Elephantopus scaber leaves was at concentration $100 \mathrm{mg} / \mathrm{mL}$. 
Table 3. Effect of ethanolic extract of Elephantopus scaber on heat induced hemolysis method

\begin{tabular}{cc}
\hline Concentration & \% Protection \\
\hline $50 \mathrm{mg} / \mathrm{mL}$ & 52,0 \\
$100 \mathrm{mg} / \mathrm{mL}$ & 94.7 \\
$120 \mathrm{mg} / \mathrm{mL}$ & 70.7 \\
Standard & 97,0 \\
\hline
\end{tabular}

\section{DISCUSSION}

Several studies have shown that the bioactive content possessed by plants has great potential to be a source of anti-inflammatory drug discovery. ${ }^{17,18}$ In the present study, we found antiinflammatory activities of extract ethanolic of Elephantopus scaber. Based on the phytochemical screening, we found that the phytochemicals constituent content possessed by extract ethanolic. In the present study were flavonoids, saponins, and tannins. The content of flavonoids, tannins, and saponins in ethanolic extract of Elephantopus scaber may be responsible for the anti-inflammatory activity.

In the present study, the extract of Elephantophus scaber could inhibit lysis of the red blood cells membrane. The red blood cells membrane is analogous to the lysosome membrane. Several studies have shown that the content of flavonoids and saponins in plants could inhibit the phospholipase A2 (PLA2s). ${ }_{12,19,20}$ Phospholipase A2 is an enzyme that acts to break down the Sn-2 fatty acid of membrane phospholipid that encloses arachidonic acid (AA) which plays an important role in the inflammatory process. ${ }^{21}$ The arachidonic acid is subsequently converted to prostaglandin by COX- 1 and COX- 2 enzymes. COX- 2 is an enzyme responsible for the inflammatory process and its activity is induced by inflammatory, hormonal, and growth factors. ${ }^{6}$ Flavonoids and saponins are also known to have an activity that can inhibit COX-2 which is a non-steroidal anti-inflammatory drug target. ${ }^{20}$ In the present study also could be seen that the extract ethanolic of Elephantophus scaber could provide protection against heatinduced hemolysis red blood cells. Ethanolic extract of Elephantophus scaber could protect the lysis of red blood cell membranes by exposure to harmful stimuli such as heat. Harmful stimuli could induce expression of TNF- $\alpha$ by activating immune response. TNF- $\alpha$ plays an important role in inflammation. TNF- $\alpha$ causes changes in vascular endothelium. In physiological conditions, leukocytes move freely along the vascular endothelium. TNF- $\alpha$ causes the vascular endothelium to become pro-inflammatory, subsequently increasing the adhesion of leukocytes to the vascular endothelium, transendothelial leukocyte migration, vascular leakage and increased thrombosis. ${ }^{22,23}$ Saponins contained in plants can inhibit TNF- $\alpha{ }^{23}$ In addition, the anti-inflammatory mechanisms in this study may be due to the ability possessed by ethanolic extract of Elephantophus scaber in inhibiting prostaglandin $\mathrm{E} 2\left(\mathrm{PGE}_{2}\right) . \mathrm{PGE}_{2}$ plays an important role in the inflammatory process by increasing the permeability of blood vesselsand causing pain. Flavonoids, saponins, and tannins present in plants have the activity to inhibit inducible Nitric Oxide Synthase (iNOS). iNOS is an NOS isoform that is highly expressed by macrophage cells during inflammation. iNOS can lead to increased production of $\mathrm{PGE}_{2}$. Therefore, a substance that can inhibit iNOS may act as an anti-inflammatory agent. ${ }^{24-28}$ Further studies are necessary to investigate and to isolate the bioactive compounds contained in the ethanolic extract of Elephantophus scaber that responsible for this anti-inflammatory action.

\section{CONCLUSION}

In the present study showed that the ethanolic extract of Elephantophus scaber has anti-inflammatory activities by in vitro assays. The presence of flavonoid, saponin and tannin 
may be responsible for the anti-inflammatory activities. The present study suggests that the ethanolic extract of Elephantophus scaber has a promising bioactive compound that can be used as an anti-inflammatory. Further investigations are needed to isolate the bioactive compound of the extract Elephantophus scaber and to confirm the mechanism that responsible for anti-inflammatory activities.

\section{CONFLICT OF INTEREST}

We declare there is no conflict of interest

\section{ACKNOWLEDGMENT}

The present study was supported by SIMLITABMAS grant in 2016 from the Ministry of Research, Technology and Higher Education of the Republic of Indonesia.

\section{REFERENCES}

1. Vane JR, Botting RM. Anti-inflammatory drugs and their mechanism of action. Inflammation Research. 1998;47(2):S78-87.

2. Vane JR. The mechanism of action of anti-inflammatory drugs. In: Serhan CN, Perez HD, editors. Advances in Eicosanoid Research. Volume 31. Berlin, Heidelberg: Springer; 2000. p. 1-23.

3. Medzhitov R. Origin and physiological roles of inflammation. Nature. 2008;454(7203):428-423.

4. Straub RH, Schradin C. Chronic inflammatory systemic diseases: An evolutionary trade-off between acutely beneficial but chronically harmful programs. Evolution, Medicine, and Public Health. 2016;2016(1):37-51.

5. Carlo C, Nicolò CB. Prostaglandin E2: Igniting the fire. Immunology and Cell Biology. 2009;87(1):510-511.

6. Ricciotti E, FitzGerald GA. Prostaglandins and inflammation. Arteriosclerosis, Trombosis, and Vascular Biology. 2011;31(5):986-1000.

7. Matsui H, Shimokawa O, Kaneko T, Nagano Y, Rai K, Hyodo I. The pathophysiology of non-steroidal anti-inflammatory drug (NSAID)-induced mucosal injuries in stomach and small intestine. Journal of Clinical Biochemistry and Nutrition. 2011;48(2):107-11.

8. Choi EM, Hwang JK. Screening of Indonesian medicinal plants for inhibitor activity on nitric oxide production of RAW264.7 cells and antioxidant activity. Fitoterapia. 2005;76(2):194-203.

9. Hammer ML, Johns EA. Tapping an Amazônian plethora: Four medicinal plants of Marajó Island, Pará (Brazil). Journal of Ethnopharmacology. 1993;40(1):53-75.

10. Lin CC, Tsai CC, Yen MH. The evaluation of hepatoprotective effects of Taiwan folk medicine "teng-khia-u." Journal of Ethnopharmacology. 1995;45(2):113-23.

11. Wang J, Li P, Li B, Guo Z, Kennelly EJ, Long C. Bioactivities of compounds from Elephantopus scaber, an ethnomedicinal plant from southwest China. 2014. (Evidence-Based Complementary and Alternative Medicine, Volume 2014, Article ID 569594).

12. Kim HP, Son KH, Chang HW, Kang SS. Anti-inflammatory plant flavonoids and cellular action mechanisms. Journal of Pharmacological Science. 2004;96(3):229-45.

13. Kasote DM, Katyare SS, Hegde MV, Bae H. Significance of antioxidant potential of plants and its relevance to therapeutic applications. International Journal of Biological Sciences. 2015;11(8):982-991.

14. Greenwell M, Rahman PK. Medicinal plants: Their use in anticancer treatment. International Journal of Pharmaceutical Sciences and Research. 2015;6(10):4103-12.

15. Hossain MA, Al-Raqmi KA, AL-Mijizy ZH, Weli AM, Al-Riyami Q. Study of total phenol, flavonoids content and phytochemical screening of various leaves crude extracts of locally grown Thymus vulgaris. Asian Pacific Journal of Tropical Biomedicine. 2013;3(9):705-10.

16. Gupta V, Chauhan S, Prakash A, Mathur A. Evaluation of in vitro and invivo anti-inflammatory activities of Parthenium camphora. RRST. 2013;5(1):33-9.

17. Beg S, Swain S, Hasan H, Barkat MA, Hussain MS. Systematic review of herbals as potential anti-inflammatory agents: Recent 
advances, current clinical status and future perspectives. Pharmacognosy Reviews. 2011;5(10):120-37.

18. Murugesan D, Deviponnuswamy R. Potential anti-inflammatory medicinal plants-A review. International Journal of Pharmacy and Pharmaceutical Sciences. 2014;6(4):43-9.

19. Hassan HS, Sule MI, Musa AM, Musa KY, Abubakar MS, Hassan AS. Anti-inflammatory activity of crude saponin extracts from five Nigerian medicinal plants. African Journal of Traditional, Complementary, and Alternative Medicines. 2011;9(2):250-5.

20. Ribeiro D, Freitas M, Tomé SM, Silva AM, Laufer S, Lima JL, et al. Flavonoids inhibit COX-1 and COX-2 enzymes and cytokine/ chemokine production in human whole blood. Inflammation. 2015;38(2):858-70.

21. Sun GY, Shelat PB, Jensen MB, He Y, Sun AY, Simonyi A. Phospholipases A2 and inflammatory responses in the central nervous system. NeuroMolecular Medicine. 2010;12(2):133-148.

22. Bradley JR. TNF-mediated inflammatory disease. The Journal of Pathology. 2008;214(2):149-60.

23. Shah BA, Chib R, Gupta P, Sethi VK, Koul S, Andotra SS, et al. Saponins as novel TNF- $\alpha$ inhibitors: Isolation of saponins and a nor-pseudoguaianolide from parthenium hysterophorus. Organic \& Biomolecular Chemistry. 2009;7(16):3230-5.

24. Park YM, Jong-Heon W, Kyung-Jin Y, JongHoon R, Yong-Nam H, Seung-Ki C, et al. Preventive effect of Ginkgo biloba extract (GBB) on the lipopolysaccharide-induced expressions of inducible nitric oxide synthase and cyclooxygenase- 2 via suppression of nuclear factor- $\kappa \mathrm{B}$ in RAW 264.7 cells. Biological and Pharmaceutical Bulletin. 2006;29(5):985-90.

25. Hämäläinen M, Nieminen R, Vuorela P, Heinonen M, Moilanen E. Anti-inflammatory effects of flavonoids: genistein, kaempferol, quercetin, and daidzein inhibit STAT-1 and NF- $\kappa \mathrm{B}$ activations, whereas flavone, isorhamnetin, naringenin, and pelargonidin inhibit only NF- $\kappa B$ activation along with their inhibitory effect on i. Mediators of Inflammation. 2007;2007:45673.

26. Lee CJ, Chen LG, Liang WL, Wang CC. Anti-inflammatory effects of punica granatum linne invitro and in vivo. Food Chemistry. 2010;118(2):315-22.

27. Park M, Cho H, Jung H, Lee $H$, Hwang KT. Antioxidant and anti-inflammatory activities of tannin fraction of the extract from black raspberry seeds compared to grape seeds. Journal of Food Biochemistry. 2014;38(3):259-70.

28. Sharma JN, Al-Omran A, Parvathy SS. Role of nitric oxide in inflammatory diseases. Inflammopharmacology. 2007;15(6):252-9. 